\title{
Revision of the concept of the Tver glacial lake in the Upper Volga Lowland in MIS 2
}

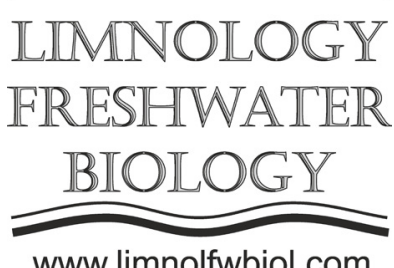

www.limnolfwbiol.com

\author{
Panin A.V. ${ }^{1,2 *}$, Sorokin A.N. ${ }^{3}$, Uspenskaya O.N. ${ }^{4}$ \\ ${ }^{1}$ Institute of Geography RAS, Staromonetniy Lane 29, Moscow, 119017, Russia \\ ${ }^{2}$ Lomonosov Moscow State University, Lengory 1, Moscow 119991, Russia \\ ${ }^{3}$ Institute of Archeology RAS, Dm.Ulianova Str., Moscow 117292, Russia \\ ${ }^{4}$ Horticulture Research Institute (VNIIOH), Vereya 500, Moscow Region 117292, Russia
}

\begin{abstract}
Hypothesis was tested of the Tver glacial lake occupying the whole Upper Volga Lowland in MIS 2, including the Dubna River basin. Geological composition of the hypothetical lake bottom was studied in a profile drilled across the Dubna River floodplain. Facial interpretation and 14C (AMS) dating revealed that lacustrine sediments were deposited not later than in MIS 3, and since at least 30 ka BP the basin was already drained by River Dubna.
\end{abstract}

Keywords: proglacial lakes, palaeohydrolgy, palaeochannels, 14C dating, stone age archaeology

\section{Introduction}

In the so-called Zabolotsky Swamp on the banks of the river Dubna (right tributary of the upper Volga) and riverine areas, 25 archaeological sites of the Stone Age are known (Sorokin et al., 2018). The key to most researchers was the idea of predominantly lacustrine nature of paleolandscape, which could be occupied only since the Pleistocene-Holocene boundary. This view was based on the concept of the well-known paleohydrologist D. D. Kvasov elaborated in 1970s on the widespread development of large glacier-dammed lakes in the upper Volga basin during the last glaciations (Kvasov, 1975; 1979). According to this hypothesis, in the Late Valdai (Ostashkov) glacial epoch, the Dubna Lowland was inundated by the extensive Tver glacial lake that occupied the whole Upper-Volga Lowland. After the drainage of this lake in the Late Glacial, River Dubna and tributaries were formed, and a number of small residual lakes were left, including, the presentday Zabolotsky Lake. It was believed that loams that lay everywhere below the surface peat cover are lacustrine sediments of a glacial lake. It was believed that the change of the loams by peat up the section indicates the drainage of the Tver Lake and transformation of the lake bottom into a marshy plain. Accordingly, it was assumed that the population of Dubna outwash lowlands can happen only at the very end of the existence of the Tver Lake when the low local elevations of the former lake bottom have become inhabitable land areas. Therefore it was believed that the life and economy of the final Palaeolithic - Neolithic population in the Dubna Lowland was closely associated with the existence and fluctuations of numerous shallow relics of the former large lake (Sidorov, Sorokin, 1997; Sidorov, 2009; Zamost'ye 2..., 2013; Lozovski et al., 2014).

In recent years, data have begun to accumulate that cast doubt on the existence of extensive dammed lakes in the upper Volga basin in the Late Valdai time (Utkina, 2017; Baranov and Utkina, 2018; Konstantinov et al., 2019; Panin et al., 2020). The existence or absence of a lake totally covering the Dubna Lowland is of great importance both for interpreting the study results of the Zabolotsky geoarchaeological area and for determining the strategy for its further research. To reconstruct the paleogeographic situation of the Late Pleistocene in the area of Minino 2 archaeological site, a complex of geological and geomorphological studies was carried out, the results of which are presented in this paper.

\section{Methods}

A profile of 11 cores 4.5-18.0 m deep was drilled across the Dubna River floodplain using the Pride Mount 80 mechanical corer, profile central point at $56.6769 \mathrm{~N}$, 38.0102 E. 14C (AMS) dating (11 dates) was produced in the Institute of Geography RAS. Macrofossil study was produced under microscope in suspension under a microscope with 400x magnification (fraction 4-250 $\mu \mathrm{m})$ and then the remainder washed and washed on a $0.25 \mathrm{~mm}$ sieve with $80 \mathrm{x}$ magnification (fraction $>250$ $\mu \mathrm{m})$. 


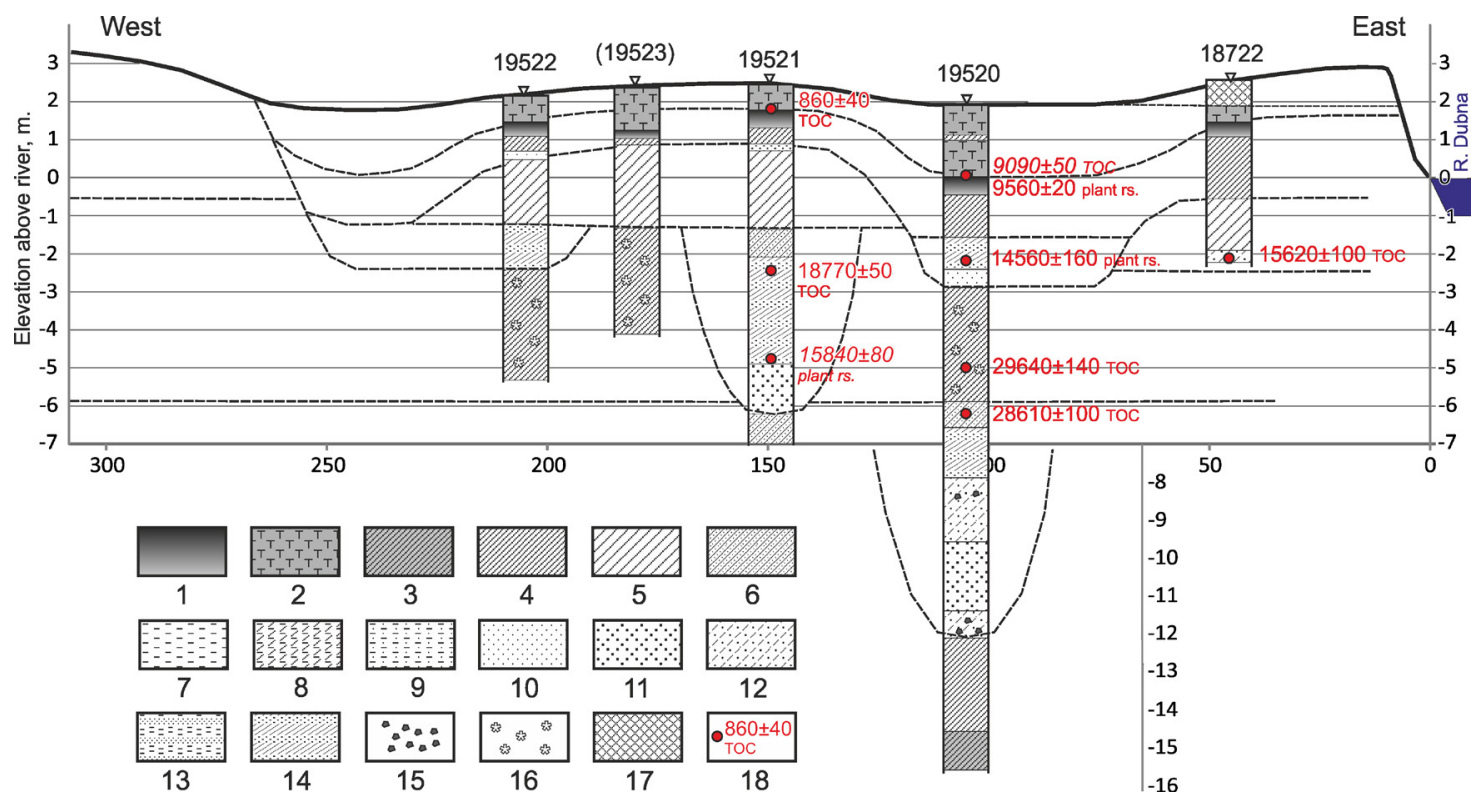

Fig.1. Coring profile across the Dubna River floodplain at the Minino 2 archaeological site.

Legend: 1 - soil; 2 - peat; 3 - peaty loam; 4 - clayey loam; 5 - loam, silty loam; 6 - sandy loam; 7 - silt; 8 - loamy silt; 9 sandy silt; 10 - fine sand; 11 - medium sand; 12 - loamy sand, silty sand; 13 - interbedded sand and silt; 14 - interbedded sand and loam; 15 - inclusions of fine gravel; 16 - large carbonate concretions; 17 -dredging dumps (loam); 18 - calendar 14C (AMS) dates, yrs ago, and dated materials: TOC - total organic carbon, plant rs. - plant macrofossils.

\section{Results and Discussion}

Lithological analysis of drilling data and AMS dates revealed three generations of river palaeochannels rising in the section from $-12 \mathrm{~m}(12 \mathrm{~m}$ below the present-day river level) to $-2-3 \mathrm{~m}$ (Fig. 1). The lowest buried paleochannel has an age of more than $30 \mathrm{ka}$. The second can be dated so far only in a wide range from 19 to $16 \mathrm{ka}$. The third generation includes two wide shallow palaeochannels dated back to $14.5 \mathrm{ka}$. They are expressed in the floodplain topography as wide hollows. Two lower generations are completely buried and can not be traced in the surface. Microfossil analysis of several samples from 18-m deep core 19520 located on floodplain $2 \mathrm{~m}$ above the river, allowed to interpret the loamy sediments to the level of $-8 \mathrm{~m} \mathrm{(} 8 \mathrm{~m}$ below the modern river) as overbank alluvium, sandy sediments at $-8-12 \mathrm{~m}-$ as active channel alluvium (palaeochannel of the first generation), and organicreach silts (gyttja) from $-12 \mathrm{~m}$ to $-16 \mathrm{~m}$ as lacustrine deposits.

Gyttja in lower part of the floodplain section indicates the existence of an ancient lake before the formation of the lowest palaeochannel that is older than $30 \mathrm{ka}$. This could be a residual lake since the Moscow ice age (MIS 6) deglaciation. Not later than $30 \mathrm{ka}$ BP the bottom of the depression was already drained by River Dubna. Compact loam rich in carbonate concretions overlying this palaeochannel forms a continuous layer from 1 to $6 \mathrm{~m}$ below the modern river. These loams represent overbank alluvia deposited on the periphery of a wide floodplain at far distance from active river channel. Seasonal inundation provided seasonally lacustrine condition over the wide floodplain, which explains the similarity of floodplain loams to typical lacustrine deposits.

Loams could also be deposited in permanent lakes formed on the periphery of the river floodplain.
Such lakes are typical of floodplains of aggrading rivers where river channels may lay higher than the floodplain. The aggradation tendency in the ancient Dubna River in the period at least from 30 to $15 \mathrm{ka} \mathrm{BP}$ is indicated by buried palaeochannels that occupy successively higher positions in the geological section. This was an apparent mechanism of the formation of the presentday Zabolotskoe Lake, as well as former floodplain lakes transformed into bogs but clearly visible in satellite imagery along Dubna River. In the Late Glacial and Early Holocene, these lakes most likely still existed. Small lakes could also exist on the floodplain in ancient river channels similar to that discovered by coring. All these reservoirs, as well as the river itself, undoubtedly played an important role in the life and economy of the ancient population.

\section{Conclusion}

The presented results lead to the conclusion that the revision of the model of geomorphology of the region is required and the concept of the Tver glacial lake that occupied the Dubna Lowland and more widely the entire upper Volga lowland in MIS 2 - may be rejected. According to the new data, the lake in the Dubna Lowland existed much earlier, and not later than $30 \mathrm{ka}$ BP the bottom of the basin had already been drained by River Dubna. This does not preclude the periodic formation of small alluvial lakes over the Dubna floodplain, but a single large lake that occupied the whole basin during the Late Valdai (MIS 2), did not exist.

\section{Acknowledgements}

Field survey, archaeological and geochronological studies were carried out with the financial support of the Russian Foundation for Basic Research, Project No. 
19-09-00143. Paleohydrological and paleolimnological reconstructions were carried out as part of the Russian Science Foundation Project No.17-17-01289.

\section{References}

Baranov D.V., Utkina A.O. 2018. Late Valdai proglacial lakes of the Upper Volga: geological and geomorphological data. In: International Conference "Paleolimnology of Northern Eurasia: Experience, Methodology, Current Status and Young Scientists School in Microscopy Skills in Paleolimnology", pp. 15-18.

Konstantinov E., Karpukhina N., Belyaev V. et al. 2019. Rostov lowland (Yaroslavl Region, Russia) - was there a gulf of proglacial lake? In: 20th Congress of the International Union for Quaternary Research (INQUA), pp. 4860-4860.

Kvasov D.D. 1975. Pozdnechetvertichnaya istoriya krupnykh ozer i vnutrennikh morey Vostochnoy Yevropy. Leningrad: Nauka. (in Russian)

Kvasov D.D. 1979. The Late-Quaternary history of large lakes and inland seas of Eastern Europe. Helsinki: Suomalainen Tiedeakatemia.

Lozovski V., Lozovskaya O., Mazurkevich A. et al. 2014. Late Mesolithic - Early Neolithic human adaptation to environmental changes at an ancient lake shore: The multilayer Zamostje 2 site, Dubna River floodplain, Central Russia. Quaternary International 324: 146-161. DOI: 10.1016/j. quaint.2013.12.060

Panin A., Astakhov V., Komatsu G. et al. 2020. Middle and Late Quaternary glacial lake-outburst floods, drainage diversions and reorganization of fluvial systems in northwestern Eurasia. Earth-Science Reviews 201. DOI: 10.1016/j.earscirev.2019.103069

Sidorov V.V. 2009. Rekonstruktsii v pervobytnoy arkheologii [Reconstruction in prehistoric archaeology]. Moscow: Taus. (in Russian)

Sidorov V.V., Sorokin A.N. 1997. Multilayer settlement Zamost 5. In: Drevnosti Zalesskogo kraya. Materialy $\mathrm{k}$ mezhdunarodnoj konferencii «Kamennyj vek Evropejskih ravnin» [Antiquities of the Zalessky Territory. Materials for the international conference "Stone Age of European Plains"]. Sergiev Posad, pp. 144-163. (in Russian)

Sorokin A.N., Gracheva R.G., Dobrovolskaya E.V. et al. 2018. Geoarkheologiya Zabolotskogo kraya (13.500-7.500 cal BC) [Geoarchaeology of the Zabolotsky Territory (13.5007.500 cal BC)]. Moscow: IA RAS. (in Russian)

Utkina A.O. 2017. To the question of the evolution of the Late Valdai glacial lakes in the Upper Volga basin. In: Geologiya, Geoekologiya i Resursnyj Potencial Urala i Sopredel'nyh Territorij [Geology, Geoecology, and Resource Potential of the Urals and Adjacent Territories] 5: 435-440. (in Russian)

Zamost'ye 2. Ozernoye poseleniye drevnikh rybolovov epokhi mezolita - neolita $\mathrm{v}$ basseyne Verkhney Volgi [Zamostje 2: Lake settlement of ancient fishermen of the Mesolithic-Neolithic epoch in the Upper Volga basin]. 2013. In: Lozovski V.M., Lozovskaya O.V., Clemente Conte I. (Eds.). Sankt-Petersburg: IIMK RAN. (in Russian) 